\title{
Stimulating Strategically Aligned Behaviour Among Employees
}

\section{Cees B. M. van Riel, Guido Berens and Majorie Dijkstra}

\begin{tabular}{|l|l|}
\hline \multicolumn{2}{|l|}{ ERIM REPORT SERIES RESEARCH IN MANAGEMENT } \\
\hline ERIM Report Series reference number & ERS-2007-029-ORG \\
\hline Publication & May 2007 \\
\hline Number of pages & 32 pages \\
\hline Persistent paper URL & \\
\hline Email address corresponding author & criel@rsm.nl \\
\hline Address & Erasmus Research Institute of Management (ERIM) \\
& RSM Erasmus University / Erasmus School of Economics \\
& Erasmus Universiteit Rotterdam \\
& P.O.Box 1738 \\
& 3000 DR Rotterdam, The Netherlands \\
& Phone: $\quad+31104081182$ \\
& Fax: $\quad+31104089640$ \\
& Email: info@erim.eur.nl \\
& Internet: $\quad$ www.erim.eur.nl \\
\hline
\end{tabular}

Bibliographic data and classifications of all the ERIM reports are also available on the ERIM website: www.erim.eur.nl 


\section{ERASMUS RESEARCH INSTITUTE OF MANAGEMENT}

\section{REPORT SERIES}

\section{RESEARCH IN MANAGEMENT}

\begin{tabular}{|c|c|}
\hline \multicolumn{2}{|c|}{ ABSTRACT AND KEYWORDS } \\
\hline Abstract & $\begin{array}{l}\text { In recent years it has become increasingly important for companies to ensure strategically } \\
\text { aligned behaviour, i.e., employee actions that are consistent with the company's strategy. This } \\
\text { study provides insights into the way companies can stimulate such behaviour through motivating } \\
\text { and informing their employees, and by providing them with the necessary capabilities. The } \\
\text { results of surveys conducted in three organisations suggest that motivating, informing, and } \\
\text { providing the necessary capabilities are essential conditions for strategically aligned behaviour to } \\
\text { occur; however, this only holds when a company has not sufficiently engaged in one or more of } \\
\text { these practices in the past. For example, in the case that employees have already been } \\
\text { sufficiently informed about the company's strategy, it would be of greater benefit to then reduce } \\
\text { efforts to inform them and increase efforts to motivate and develop capabilities. }\end{array}$ \\
\hline Free Keywords & Capability development, Employee behaviour, Information, Motivation, Strategic alignment \\
\hline Availability & $\begin{array}{l}\text { The ERIM Report Series is distributed through the following platforms: } \\
\text { Academic Repository at Erasmus University (DEAR), DEAR ERIM Series Portal } \\
\text { Social Science Research Network (SSRN), SSRN ERIM Series Webpage } \\
\text { Research Papers in Economics (REPEC), REPEC ERIM Series Webpage }\end{array}$ \\
\hline Classifications & $\begin{array}{l}\text { The electronic versions of the papers in the ERIM report Series contain bibliographic metadata } \\
\text { by the following classification systems: } \\
\text { Library of Congress Classification, (LCC) LCC Webpage } \\
\text { Journal of Economic Literature, (JEL), JEL Webpage } \\
\text { ACM Computing Classification System CCS Webpage } \\
\text { Inspec Classification scheme (ICS), ICS Webpage }\end{array}$ \\
\hline
\end{tabular}




\title{
STIMULATING STRATEGICALLY ALIGNED BEHAVIOUR AMONG EMPLOYEES
}

\author{
Cees B. M. van Riel \\ RSM-Erasmus University \\ PO Box 1738, 3000 DR, Rotterdam, the Netherlands \\ Tel: +31 10 4081914, Fax: +31 104089012 \\ e-mail: criel@rsm.nl \\ Guido Berens \\ RSM-Erasmus University \\ PO Box 1738, 3000 DR, Rotterdam, the Netherlands \\ Tel: +31 10 4082260, Fax: +31 104089012 \\ e-mail: gberens@rsm.nl \\ Majorie Dijkstra \\ RSM-Erasmus University \\ PO Box 1738, 3000 DR, Rotterdam, the Netherlands \\ Tel: +31 10 4081983, Fax: +31 104089012 \\ e-mail: mdijkstra@rsm.nl
}

Draft, May 2007 


\title{
STIMULATING STRATEGICALLY ALIGNED BEHAVIOUR AMONG EMPLOYEES
}

\begin{abstract}
In recent years it has become increasingly important for companies to ensure strategically aligned behaviour, i.e., employee actions that are consistent with the company's strategy. This study provides insights into the way companies can stimulate such behaviour through motivating and informing their employees, and by providing them with the necessary capabilities. The results of surveys conducted in three organisations suggest that motivating, informing, and providing the necessary capabilities are essential conditions for strategically aligned behaviour to occur; however, this only holds when a company has not sufficiently engaged in one or more of these practices in the past. For example, in the case that employees have already been sufficiently informed about the company's strategy, it would be of greater benefit to then reduce efforts to inform them and increase efforts to motivate and develop capabilities.
\end{abstract}

Key words: capability development, employee behaviour, information, motivation, strategic alignment

\section{INTRODUCTION}

The successful implementation of an organisation's strategy is essential for the optimal performance of the organisation (Noble, 1999). In many cases, strategy implementation does not merely involve adjusting organisational structures and control systems, but requires complex interaction processes between managers and employees (Skivington and Daft, 1991). The complexity of strategy implementation has increased in recent decades as companies increasingly provide their employees with greater autonomy and flexibility in doing their jobs (Ichniowksi et al., 1996). Reflecting this complexity, Noble (1999, p. 120) defines strategy implementation as "the communication, interpretation, adoption, and enactment of strategic plans”. Previous research on implementation has mainly focused on the "interpretation" and "adoption” parts of this definition, under the headings of “strategic consensus” (Kellermanns et al., 2005) and “strategic commitment” (Noble and 
Mokwa, 1999; Wooldridge and Floyd, 1989), respectively. In contrast, the behavioural or “enactment” aspect has been relatively under-researched. Focusing on employee behaviour is important because employee consensus about, and commitment to, the company strategy is unlikely to automatically translate into a successful implementation. As is commonly demonstrated in social psychology research, people do not always behave in correspondence to their attitudes (e.g., Fazio and Zanna, 1981).

In this paper, we focus on the influence of different managerial efforts on the degree to which employees actually behave in accordance with the company's strategic objectives. Following Gagnon and Michael (2003), we term this type of behaviour "strategically aligned behaviour" (SAB), which is defined as "on-the-job actions that are aligned with the strategy" (p. 26). SAB can be seen as a subset of two types of employee behaviours which have been discussed extensively in the relevant literature: (1) task performance or in-role behaviour, and (2) contextual performance or organisational citizenship behaviour. Task performance refers to "activities that either supported or directly contributed to the transformation of the organization's inputs to outputs”, while contextual performance refers to “activities that supported the social and psychological context in which the organization's technical core was embedded” (LePine et al., p. 53). Depending on the nature of the organisation's strategy, SAB can be a type of task performance (e.g., increasing efficiency) or a type of contextual performance (e.g., increasing internal cohesion). The key characteristic is that it contributes to the realisation of the strategy. Furthermore, SAB can involve the behaviour of mid-level and operational managers as well as lower-level workers.

Previous research has suggested that the degree of success in implementing a company's strategy is influenced by several factors controlled by managers (see Noble, 1999). For example, the company's internal reward and control systems determine the degree to which employees attach importance to the company's strategic objectives (Strahle et al., 1996) and behave in accordance with them (Besser, 1995; McMullen and Shepherd, 2006). In addition, Gupta (1987) showed that a higher degree of decentralisation within an organisation results in a more successful strategy implementation. On the other hand, at least some type of formal cross-functional structure seems to be necessary to enable cooperation among functions and departments (Cornelissen et al., 2006). Other studies showed that the degree to which senior management supports the company strategy is related to the degree to which employees accept the strategy (Caldwell et al., 2004) and to the performance of employees in implementing the strategy (Noble and Mokwa, 1999). Schneider et al. (2003) showed that employee training and development can enhance employee understanding of the 
organisation's strategy, while Lee and Miller (1999) argued that training and development can enhance the effectiveness of strategy implementation. Finally, previous studies have also shown that the amount and accuracy of information concerning the strategy affects the degree of strategic consensus (Rapert et al., 2002) and the overall success of the strategy implementation (Hambrick and Cannnella, 1989).

The factors identified in previous research as influencing the degree of success in implementing a company's strategy can be broadly distinguished into "hard” factors, related to organisational systems and structure, and "soft” factors related to interactive processes between managers and employees (Skivington and Daft, 1991). In the present paper, we focus on the role of three sets of "soft” variables: (1) motivating efforts, (2) capability development, and (3) information. These factors correspond to three broad types of variables postulated as antecedents of employee job performance, namely "willingness”, “capacity”, and “opportunity” (Blumberg and Pringle, 1982; Mitchell and Larson, 1987; Peters and O'Connor, 1980).

Our research extends previous work on strategy implementation in three ways. First, we focus on the role of individual managerial actions in strategy implementation, rather than the role of organisation-level factors. The majority of previous studies on strategy implementation have examined factors that influence implementation success at the firm level (see Noble, 1999), meaning that individual managerial actions that influence the attitudes and behaviour of individual employees have often been overlooked (Johnson et al., 2003). Second, our research primarily seeks to explain employee behaviour. Most studies that investigate employee responses to their organisation's strategy focus on either the attitudes of employees toward the strategy, i.e., strategic commitment (Caldwell et al., 2004; Gagné et al., 2000), or on employee understanding of the strategy, i.e., strategic consensus (Bowman and Ambrosini, 1997; Kellermanns et al., 2005); however, it is important for companies to know whether employees will actually behave in accordance with the company's strategic initiatives. Third, we include multiple types of antecedents of SAB, including not only motivation-related variables, but also variables related to capabilities and opportunities. We also examine the interactive effects of these types of antecedents, as it seems likely that the effect of one type of action is dependent on the degree to which the others are utilised. Most of the previous studies that focused on the link between management actions and SAB have mainly looked at only one type of antecedent, with a focus on managerial actions related to motivation (e.g., Noble and Mokwa, 1999; Piercy et al., 2006). 


\section{HYPOTHESES DEVELOPMENT}

The theoretical model for this study is shown in Figure 1. Based upon past theorising and research, we argue that managerial efforts to (1) motivate employees to contribute to the company's strategy, (2) provide them with the capabilities necessary to execute the strategy, and (3) inform them about the strategy and their role in its implementation, influence the degree to which employees behave in a way that supports the strategy (i.e., SAB). We also propose that these types of efforts influence each other and have interactive effects on SAB in the sense that the effectiveness of one type of effort depends on whether the other two are present. We elaborate on these propositions below.

\section{INSERT FIGURE 1 ABOUT HERE}

\section{Influence of motivating efforts on strategically aligned behaviour}

One key antecedent of employee behaviour and performance is the degree to which employees are motivated to perform the tasks assigned to them. Several authors have addressed the managerial factors that influence this motivation (see Mitchell and Larson, 1987, for an overview). For example, Locke’s (1978) goal setting theory posits that providing employees with clear goals increases their motivation and performance; however, later empirical studies regarding goal setting established that it is not only the goal that is important, but also the manner in which it is 'sold' to employees (Latham et al., 1988). When a clear rationale for the goal is provided, motivation and performance are at a higher level than when instructions are given without any justification. In addition, allowing employees to participate in the setting and implementation of the goals leads to a greater commitment in achieving them (e.g., Argyris, 1957; Sagie and Koslowsky, 1994).

Similarly, Smidts et al. (2001) argue that a stimulating communication climate, which is characterised by (1) openness, (2) participation in decision making, and (3) supportiveness, increases employee identification with their organisation. This occurs because such a climate increases the employee's sense of belonging to the organisation (self-categorisation), as well as enhancing the benefits of being a member of the organisation (self-enhancement). In turn, employee identification can lead to greater employee efforts to implement the strategy (Lee and Miller, 1999). On the negative side, research on organisational silence has shown that when management does not stimulate employee participation and does not acknowledge 
employee opinions, a "climate of silence” is created, in which employees feel reluctant to speak out on important issues (Morrison and Milliken, 2000). This in turn leads to a decrease in employee commitment (Bowen and Blackmon, 2003; Morrison and Milliken, 2000). We propose the following hypothesis:

Hypothesis 1: Managerial efforts aimed at (1) providing a rationale for the company's strategy, (2) enabling employee participation in the implementation of the strategy, and (3) acknowledging employee opinions and feelings regarding the strategy, lead to more SAB by employees.

\section{Influence of capability development on strategically aligned behaviour}

In addition to motivation, a widely recognised antecedent of employee behaviour is the degree to which employees are capable of performing their jobs. Naturally, the degree of SAB displayed by employees is dependent on whether they have the capabilities to carry out the required behaviour (e.g., Peters and O'Connor, 1980; Vroom, 1964). These capabilities may include skills, habits, and tacit or explicit knowledge (Schmidt et al., 1986). Managerial actions to build such capabilities may include formal or informal training programs, or the organisation-wide dissemination of explicit knowledge (Bloodgood and Morrow, 2003).

In addition to building relevant employee knowledge and skills, management attention to the development of employee capabilities may increase employees' feelings that the organisation cares about their well-being (Lee and Miller, 1999). In turn, these feelings may stimulate employee motivation and initiative, and ultimately SAB. An effort to develop capabilities can give employees the feeling that management is truly committed to actually implementing the strategy (Carter et al., 1999). Furthermore, aside from the effect of employees’ actual capabilities, Bandura’s (1997) self-efficacy theory suggests that the degree to which employees perceive themselves to be capable of executing the strategy can be an important motivating factor. A large number of empirical studies have confirmed that perceived capabilities, independently of actual capabilities, influence people's performance on several tasks (see Judge et al., 2007). Therefore, we posit:

Hypothesis 2a: Managerial efforts to provide employees with capabilities to execute the organisation's strategy lead to greater SAB.

Our reasoning regarding the effects of capability development on behaviour suggests that these efforts can also influence the degree to which employees perceive that management makes an effort to motivate them; that is, capability development does not serve merely as a 
direct facilitator of behaviour, but also enhances employees’ feelings that the company makes an effort to involve them in the strategy. Therefore, we hypothesise:

Hypothesis 2b: Managerial efforts to provide employees with the capabilities to execute the organisation's strategy lead to the perception of a greater effort by the company in motivating employees to contribute to the strategy.

In addition, efforts to develop capabilities related to an organisation's strategy are likely to lead to increased understanding of the strategy by employees and greater insight into their role in implementing the strategy. Formal training and other activities aimed at providing employees with the capabilities to implement the organisation's strategy (e.g., mentoring) are likely to make that strategy more salient, thereby increasing employee understanding of it (Schneider et al., 2003). These types of activities can also function as socialisation mechanisms that help to make new employees familiar with organisational values (Chatman, 1989; Louis et al., 1983), thereby facilitating understanding of strategic objectives. Therefore, employees who receive a lot of training and other capability development opportunities are more likely to perceive management as providing sufficient information regarding the strategy than employees who do not receive such opportunities. We hypothesise:

Hypothesis 2c: Managerial efforts to provide employees with the capabilities to execute the organisation's strategy lead to a perception of greater effort by the company in informing employees of the strategy.

\section{Influence of informing efforts on strategically aligned behaviour}

As argued by Blumberg and Pringle (1982), employees not only need to be motivated and capable, but they also need to be provided with the opportunity to perform a desired behaviour. Empirical studies have demonstrated that this opportunity is an important determinant of employee behaviour and performance (Kane, 1997; Stewart and Nandkeolyar, 2006). One variable that provides this opportunity is the information that managers provide about the company strategy (Blumberg and Pringle, 1982). Peters and O'Connor (1980) show that a lack of the necessary information required to perform an assigned job is a common problem that impedes employee performance. According to Boswell (2006), two types of information are relevant in terms of implementing a company's strategy: (1) information about the strategy itself, and (2) information about the employee's role in the 'big picture' of the strategy. That is, in order to contribute to the implementation of a strategy, employees should know what the strategy entails on an abstract level and how they can contribute to its implementation. 
In addition to providing employees with sufficient opportunity to perform the desired behaviours, information about the organisation's strategy can also reduce employees' feelings of uncertainty regarding their jobs (Bordia et al., 2004; Schweiger and Denisi, 1991). When employees feel less uncertain, they are more likely to feel committed to the organisation and more likely to perform better in their jobs (Hui and Lee, 2000; Schweiger and Denisi, 1991). Therefore, we hypothesise:

Hypothesis 3a: Managerial efforts to provide employees with information about the organisation’s strategy (in general and regarding the role of employees in strategy implementation) lead to more SAB.

As in the case of capability development, our reasoning regarding the effect of information on behaviour implies that these efforts also influence the degree to which employees perceive the company as undertaking efforts to motivate them with respect to the strategy.

Hypothesis 3b: Managerial efforts to provide employees with information about the organisation's strategy (in general and regarding the role of employees in strategy implementation) lead to a perception of greater effort in motivating employees to contribute to the strategy.

We also expect that managers' efforts to inform employees about the strategy in general increases the degree to which employees perceive managers as providing information about their role in implementing the strategy. The reason for this is that employees who have more information about the strategy can derive from this an understanding of how to contribute (Boswell, 2006). Therefore, we hypothesize:

Hypothesis 3c: Managerial efforts to provide employees with information about the organisation's strategy in general lead to a perception that greater effort was given to inform employees about their role in strategy implementation.

\section{Interactive effects of motivating efforts, capability development, and information}

In addition to the main effects of the three types of managerial efforts, it seems likely that efforts aimed at motivating, informing, and developing capabilities interact with each other in the sense that the effect of any one of these types of efforts is strongly diminished or even absent when the other two types are not present (Blumberg and Pringle, 1982). For example, when an employee is motivated to do something, but is not provided with the capabilities or the opportunity to do so, the motivation is unlikely to lead to actual behaviour. Vroom (1960) already proposed that motivation and capabilities interact in producing 
behaviour, and demonstrated empirically that the motivating effect of employee participation in decision-making is greater for highly capable employees than for employees with lower capabilities. Similarly, Bandura's (1997) self-efficacy theory states that the influence of incentives depends on the degree to which people perceive themselves as capable of executing the desired behaviour. Conversely, Judge et al. (2007) showed that the influence of this self-efficacy is stronger when difficult goals are set (a factor known to influence motivation).

To the interactive effects of motivation and (actual) capabilities, Blumberg and Pringle (1982) added situational opportunities, proposing that opportunities interact with both motivation and capabilities. Pringle (1994) tested this proposition empirically, but he only found support for the interactive effect of motivation and capability. This suggests that opportunity is not always essential for performance to occur, presumably because in many cases the opportunity is the same for all persons involved; however, opportunity would moderate the effects of both motivation and capabilities where substantial differences in opportunities exist between different employees (Peters et al., 1982; Pringle, 1994). Therefore, we propose that managerial actions aimed at motivation, capability development, and informing, will interact with each other in their effects on SAB. Specifically, we hypothesise:

Hypothesis 4: The influence of managerial efforts to motivate employees regarding the strategy is stronger when (1) there are more efforts to develop employee capabilities regarding the strategy and (2) there are more efforts to inform employees about the strategy (in general and regarding the role of employees in implementation).

\section{METHOD}

To test our model, data were collected from three large companies via an online survey. The first company (Organisation 1) is a large logistics company employing approximately 140,000 people. Its main strategic objective at the time of this study dealt with operational efficiency. Optimising efficiency in its business activities has always been important to the company, but recently the company defined it as its key strategy in order to cope with external market pressure and enhanced competition. The second company (Organisation 2) is an insurance company with approximately 6,500 employees. It consists of a head office and six divisions. This company had recently introduced a set of key values in order to cope with growing pressure from society in terms of ethical business conduct. In addition, the company 
had recently made acquisitions and wanted to stimulate integration of the new business units into the organisation. Therefore, the values served a dual purpose: (1) stimulating ethical awareness among employees, and (2) increasing internal cohesion between the "old” and "new" divisions. The third company (Organisation 3) is a large manufacturing company employing approximately 125,000 people. It consists of a head office and five divisions. This company recently introduced strategic plans to (1) increase internal cooperation among the divisions and (2) stimulate focus on the added value of its products.

\section{Respondents and procedure}

Given that Organisation 1 wanted to focus the survey on its management-level employees, all of the company's top and middle-level managers (a total of 2,923 employees) were asked to participate in the study. Of these, 903 participated, yielding a response rate of 30.9\%. In Organisation 2, a random sample was taken of 2,513 employees, stratified according to business units and functional levels. The overall response rate was 35.8\% ( $n=900)$. In Organisation 3, as in Organisation 1, its management was interested in the opinions of higherlevel employees only. Therefore, a stratified random sample of 4,797 higher-level employees was drawn from all six units. The overall response rate was $14.5 \%(n=696)$. The main reason for this relatively low response rate seems to have been the relatively complex strategy adopted in Organisation 3, making it more difficult for employees to answer all the questions.

In the questionnaire, employees were first asked for their opinion on the different types of managerial efforts within their company. The following questions focused on the degree to which the employees were familiar with the organisation's strategy and their understanding of the meaning of the strategy. The employees were then questioned about the degree to which they behaved in agreement with this strategy (i.e., SAB). Finally, employees were asked to provide their age, gender, job position, organisational tenure, and the business unit or division for which they worked. Responses to the questionnaire were anonymous.

\section{Measures}

Employee perceptions of managerial efforts were measured using formative scales, as each type of effort refers to a range of different behaviours that together define the type, rather than an underlying trait of which the behaviours are manifestations (Jarvis et al., 2003). Traditional methods of examining scale reliability and validity, which are based on correlations between the items used to measure a construct, are irrelevant for formative scales; instead, we applied the following steps, as suggested by Diamantopoulos and 
Winklhofer (2001): content specification, indicator specification, assessing potential indicator collinearity, and assessing external validity.

Motivating efforts. As discussed above, managers' efforts to motivate employees to implement a strategy fall into three categories: (1) providing a rationale for the company's strategy, (2) allowing employee participation in the determination and/or implementation of the strategy, and (3) acknowledging employee opinions and feelings regarding the strategy. Therefore, we measured managerial efforts to motivate employees by focusing on (1) openness in communication, (2) participation in decision-making, and (3) the feeling that one is being taken seriously. We also included three general items related to the degree to which the manager and internal media made efforts to involve employees with the company. These items were rated on three 5-point Likert scales. Correlations between the items were modest, ranging between 0.26 and 0.76 for the three organisations.

Given our sample size, correlations of such magnitude are unlikely to lead to collinearity problems (Grewal et al., 2004). This was verified by examining the weights of the items in testing the model (which was done using partial least squares [PLS]; see below). If all items have the same sign, this implies that all items contribute to the construct; this is also an indication of validity (Tenenhaus et al., 2005) ${ }^{\mathrm{i}}$. Indeed, the weights for all six items were positive, although the items related to openness and the motivating efforts of managers and internal media had the strongest weights for all three organisations.

Capability development. Following Bloodgood and Morrow (2003), we specified the content of capability development efforts as (1) providing knowledge and other resources, and (2) providing training. We measured perceived capability development efforts using two items related to resources and training provided to apply the strategy in day-to-day work. Correlations between the items ranged from 0.30 to 0.68 in the three organisations, which could not be expected to yield collinearity problems. In addition, the weights of all three items were positive.

Informing efforts. We argued above that two types of information are relevant in terms of stimulating SAB: information about the strategy as such, and information about the employees’ role in implementing the strategy (Boswell, 2006). Following Smidts et al. (2001), we operationalised information about the strategy itself using three items concerned with the degree to which employees felt that the company kept them sufficiently informed about the company's strategy (through management and internal media). The correlations between the items ranged between 0.33 and 0.58 , which again could not be expected to produce collinearity problems. The weights of all three items were also positive in testing the 
model. We operationalised information about the role of employees in implementing the strategy using four items dealing with the degree to which the company kept employees sufficiently informed about how their work relates to the tasks of other employees and how their work contributes to the overall strategy. These correlations ranged between 0.19 and 0.73, and all four items had a positive weight.

Strategically aligned behaviour. Five items were used to assess the degree to which employee behaviour was in alignment with the company's strategy. One of these items was "Most of my peers actively take initiatives to pursue this major goal in their daily activities", while another was “Most of my peers actively discuss this major goal amongst themselves”. These items were based on the construct of organisational citizenship behaviour, particularly on the dimensions labelled "individual initiative” and "interpersonal helping” (Moorman and Blakely, 1995). Based on LePine et al.’s (2002) review, we treat these items as being reflective rather than formative. To avoid social desirability bias, we asked respondents to rate the extent to which most members of their division performed SAB, rather than the extent to which they themselves performed these behaviours. Fisher (1993) has shown that this indirect questioning method is an effective technique in avoiding social desirability bias. All items were rated on 5-point Likert scales. We calculated the composite reliability of the scale in the manner recommended in the literature on PLS (Tenenhaus et al., 2005, Eq. 9). This reliability was $0.94,0.92$, and 0.95 for Organisations 1 , 2, and 3, respectively, which is well above the recommended cutoff of 0.70 .

\section{RESULTS}

We tested our hypotheses about the relationship between managerial efforts and the $\mathrm{SAB}$ of individual employees using the data obtained from Organisation 1. We used the data obtained from the other two organisations to validate the resulting model. In addition, we explored the differences between the organisations in terms of the effects of managerial actions on SAB.

\section{Results for Organisation 1}

The descriptive statistics and correlations of all of the items for Organisation 1 are shown in Tables I and II. The means for most items are slightly above the midpoint of the scale (which is 3), while the items measuring managerial efforts show weak to moderate correlations with the items measuring SAB (ranging from 0.09 to 0.35 ). 
INSERT TABLE II ABOUT HERE

To test our hypotheses, we estimated a structural equations model. When a model includes formative indicators, as with our model, estimation procedures based on maximum likelihood, such as LISREL, are generally problematic to use (Diamantopoulos and Winklhofer, 2001). Therefore, we used PLS, which is a less restrictive approach to structural equations modelling that is based on least squares rather than maximum likelihood. To test the model, we used the program PLS-GUI 2.0.1 (Li, 2005). Following the recommendations by Tenenhaus et al. (2005), we determined the significance of the structural coefficients through ordinary least squares (OLS) regressions using the latent variable scores estimated through PLS. Similarly, as recommended by Chin et al. (2003), we estimated the interaction effects through moderated OLS regressions using the latent variable scores.

Given that perceptions of both managerial efforts and SAB can be expected to be related to other aspects of the work environment, it is important to control for the influence of these aspects to avoid testing spurious relationships. First, both perceived managerial efforts and SAB are likely to differ between the different divisions of a company because of differences in workforce characteristics or "hard" managerial factors such as policies and structure. Second, previous research has shown that gender, organisational tenure, and age influence employee attitudes regarding the company that they work for (Kreiner and Ashforth, 2004; Mathieu and Zajac, 1990). Finally, Kreiner and Ashforth (2004) demonstrated that employee attitudes are influenced by job position: managers tend to identify more strongly with their organisations than non-managers. Therefore, we included division, gender, organisational tenure, age, and manager (vs. non-manager) as control variables in the model.

The results of the model are shown in Figure 2. Regarding the main effects of perceived managerial efforts on $\mathrm{SAB}$, we note that perceived motivating efforts by management have a significant positive effect, as expected (Hypothesis 1). Capability development efforts also have a significant positive effect on behaviour, confirming Hypothesis 2a. We also found that capability development has a significant positive influence on perceived motivating efforts (Hypothesis $2 \mathrm{~b}$ ) and perceived informing efforts, both in terms of the strategy in general and the role of employees in its implementation (Hypothesis 
2c) . The latter implies that capability development efforts have both a direct effect on behaviour and an indirect effect mediated via perceived motivating and informing efforts. Efforts undertaken to inform employees of the strategy as such have a significant direct effect on SAB, but informing efforts regarding the employee's role do not (partially confirming Hypothesis 3a). However, both types of informing efforts have a significant positive effect on perceived motivating efforts (Hypothesis 3b), and thereby an indirect effect on behaviour. Finally, efforts to inform employees about the strategy as such have a significant positive effect on perceived efforts by the company to inform employees of their roles (confirming Hypothesis 3c).

\section{INSERT FIGURE 2 ABOUT HER}

As hypothesised, there was a significant positive three-way interaction among motivating efforts, capability development efforts, and efforts aimed at informing employees about the strategy in general. This implies that the effect of each of the three types of efforts is diminished when either one of the other two is low. For example, Figure 3 shows that the influence of informing efforts (regarding the strategy in general) on behaviour is strong when both motivating efforts and capability development efforts are high $(\mathrm{b}=0.48)$ and weak when capability development efforts are low $(b=0.18)$, motivating efforts are low $(b=0.02)$, or both are low together $(\mathrm{b}=0.12)$.

\section{INSERT FIGURE 3 ABOUT HERE}

\section{Validation of the model for Organisations 2 and 3}

The model results for Organisations 2 and 3 are shown in Table III. The results for Organisation 1 are also shown for comparison, as are the effect sizes of the significant coefficients. The latter are defined as the squared partial correlations between the independent variable and the dependent variable, holding all other variables in the model constant (Cohen, 1988). They can be interpreted as the percentages of variance in the dependent variable uniquely attributable to the independent variable. Several differences between the organisations are apparent. First, the effect of capability development on SAB is stronger for Organisations 2 and 3 than for Organisation 1, while the effect of efforts to inform employees about the strategy in general is weaker for organisations 2 and 3 than for 
Organisation 1. Second, the effect of informing employees about their role in implementing the strategy is significant only for Organisation 3. The non-significant effects of both types of informing in Organisation 2 might reflect the fact that the strategy in this organisation was rather straightforward, consisting of a set of core values rather than a complex strategic plan. For this reason, lesser informing efforts were required. This is confirmed by the frequency distribution for employees' self-reported familiarity with the strategy and the codes we assigned to employees' understanding of the organisation's strategy ${ }^{\mathrm{ii}}$. In Organisation 1, $82.1 \%$ of the respondents indicated that they were familiar with the strategy, while $74.2 \%$ correctly described the organisation's strategy. In Organisation 3, self-reported familiarity with the two considered strategies was 84.5 and $87.5 \%$, while understanding of these two strategies was 42.7 and $47.8 \%$. In contrast, self-reported familiarity was $93.2 \%$ in Organisation 2, and understanding was $84.3 \%$. These percentages were substantially higher than those recorded for the other two organisations. In Organisation 2, therefore, there may have been less need to inform employees about the strategy. In Organisation 3, the degree of understanding of the strategies was much lower than that in the other two organisations. This could explain our finding that the effect of informing employees about their role in implementing the strategy was only significant for this organisation.

Another noteworthy difference between the organisations is the interactive effects of motivating efforts, capability development, and informing efforts. The hypothesised threeway interaction among the three types of efforts was not found for Organisations 2 and 3, but was evident in Organisation 1. This suggests that in Organisations 2 and 3, the three types of effort were not all necessary conditions for SAB to occur. However, in both organisations there are significant two-way interactions among the types of efforts. In Organisation 2, there is a significant positive interaction between motivating efforts and capability development. Specifically, the effect of motivating efforts on SAB is stronger when employees perceive managers as providing a great number of capability development opportunities $(b=0.31)$ than when they perceive management as providing few such opportunities ( $b=0.14$; Figure 4). In Organisation 2, there are no significant interaction effects involving managerial efforts to inform employees. It therefore appears that in this organisation, informing efforts regarding the strategy were not absolutely necessary for motivating or capability providing efforts to be effective. This is consistent with our finding that the main effects of informing are less significant for this organisation than for the other two. 
In Organisation 3, there is a significant positive interaction between motivating efforts and efforts to inform employees of their roles in strategy implementation. This interaction, shown in Figure 5, implies that managerial efforts to inform employees have a greater effect on SAB when there are many motivating efforts by managers $(b=0.25)$ than when there are few motivating efforts $(b=0.08)$. In other words, providing information about the way in which employees can contribute to the organisation's strategy is necessary for motivating efforts to be effective.

INSERT FIGURE 5 ABOUT HERE

\section{DISCUSSION}

This study shows that strategically aligned behaviour (SAB) by employees is directly stimulated by managers' efforts aimed at motivating employees to contribute to the strategy and at providing the capabilities needed to implement the strategy. The positive effect of efforts to motivate employees is consistent with findings by Piercy et al. (2006) that perceived organisational support positively influences employee role performance. Of the motivating efforts considered in the present study, openness made the greatest contribution to SAB; acknowledging employee opinions and allowing participative decision-making were less influential. This is consistent with Noble and Mokwa's (1999) finding that while middle managers appreciate autonomy (participative decision-making) in implementing a strategy, this by itself is unlikely to improve their implementation performance.

Managerial efforts to provide employees with information about the strategy and their role in implementing the strategy had a direct effect on employee behaviour in only one of the organisations that we studied. These findings are consistent with Blumberg and Pringle's (1982) predictions and Pringle's (1994) findings that capacity and willingness are generally more important drivers of performance than opportunity. One reason for this result could be a lack of variance in the degree of opportunity in many situations (Pringle, 1994). Indeed, in the organisation for which neither of the two informing efforts had a significant effect, employee familiarity and understanding regarding the organisation's strategy were very high, presumably because the strategy was relatively straightforward. Therefore, it could be the case that employees already had sufficient information concerning the strategy to enable them 
to implement it. In the organisations in which one of the two types of informing efforts had a significant effect on behaviour, employee familiarity and understanding were substantially lower, presumably because the strategies were more complex in these organisations. Presumably, it would appear that at least some of the employees did not have sufficient information to implement the strategy.

An alternative explanation for these differences might be the functional level of the respondents. In the organisations for which informing efforts did have an influence, attention was focused on higher-level employees, while in the other organisation all employees were included. It might be the case that information about the strategy is especially important for higher-level employees.

While informing efforts might not always directly stimulate $\mathrm{SAB}$, our findings show that they can indirectly influence SAB via their influence on perceived motivating efforts. That is, managerial efforts to inform employees about the organisation's strategy and their role in implementing it lead to more favourable perceptions by employees regarding the degree to which managers involve employees with the strategy. This implies that perceptions of the different types of effort exerted by managers are not independent of each other.

To our knowledge, this study is the first to examine the interactive effects of different types of managerial efforts in the context of SAB. Consistent with Blumberg and Pringle's (1982) predictions, we found significant interaction effects among the three types of efforts. In one of the organisations that we studied, all three types of actions appeared to be necessary in order for SAB to occur. In the organisation in which familiarity with the strategy was already high, only efforts aimed at motivating employees and providing them with capabilities appeared to be necessary conditions. In Organisation 3, in which understanding of the strategy was relatively low, only motivating efforts and efforts to inform employees about their role in implementing the strategy were necessary. These findings are consistent with Pringle's (1994) suggestion that the whether the three types of factors are necessary, depends on the context.

One possible limitation of these conclusions concerns the presence of common method bias in our results, i.e., variance between the perceptions of managerial actions and $\mathrm{SAB}$ that is due to the fact that these constructs were measured in the same questionnaire (Podsakoff et al., 2003). For example, respondents might have tried to be consistent in their answers throughout the questionnaire, or they might have avoided giving answers that could put themselves in an unfavourable light (social desirability bias). We tried to limit the latter possibility by not asking respondents directly about their behaviour, but by indirectly 
inquiring about the behaviour of their colleagues (Fisher, 1993). To avoid other possible sources of common method bias, we took care to keep questions simple, specific, and unambiguous. In addition, we separated the measures of managerial actions from those of SAB by inserting questions related to familiarity and understanding of the strategy between them (Podsakoff et al., 2003). However, to completely eliminate concerns about common method bias, future studies should examine the effects of managerial efforts on SAB when these constructs are measured through different sources.

For the interaction effects that we found, we can exclude the presence of common method bias with more confidence. Evans (1985) demonstrated that spurious interaction effects due to this type of bias never account for more than $0.5 \%$ of the variance in the dependent variable. The percentages of variance explained by our significant interactions were all approximately 1\% (see Table III).

Our findings suggest that to ensure that employees contribute to the implementation of the organisation's strategy in their day-to-day work, managers should make sufficient efforts to engage employees with the strategy (e.g., by participative decision-making), provide employees with the right capabilities, and inform them about the strategy. In addition, all three of these activities are necessary, as the effectiveness of one type of action is slight when the other actions are not engaged in full. For example, when management gives abundant information about the strategy and how to implement it, but fails to engage employees with the strategy or to provide them with the necessary capabilities to implement the strategy, employees are unlikely to take the strategy into account in their behaviour. Therefore, not only should managers pay attention to all three of these types of actions, ideally they should also track in some way the success of these actions. However, this only holds when the company has not already sufficiently engaged in one or more of these actions in the past. For example, when employees have already been adequately informed about the company's strategy, it is not necessary to give them further information on the strategy. Instead, management should focus on engaging employees and enhancing their capabilities. 


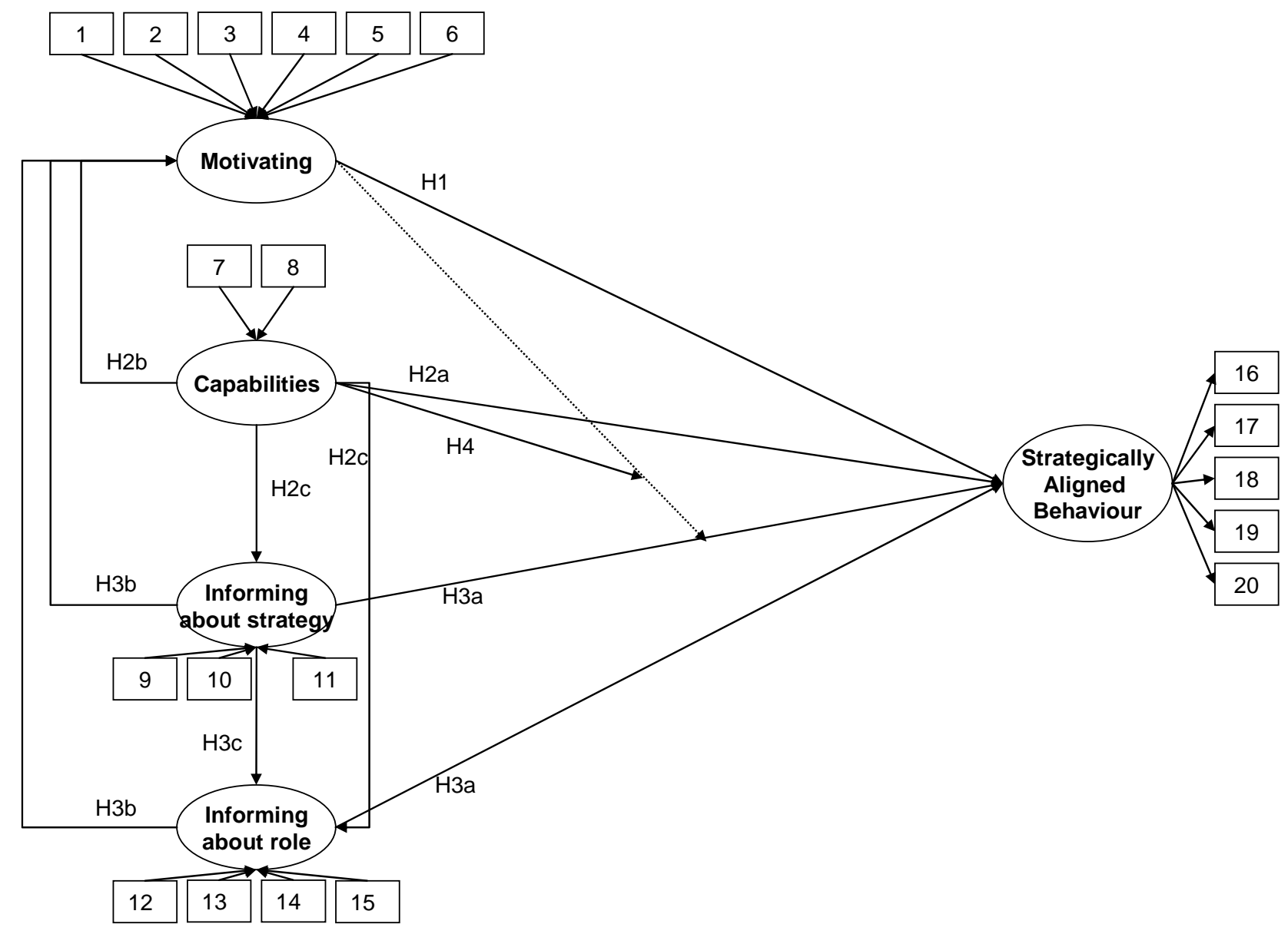

Figure 1. Research model

The numbers of the indicators correspond to the numbers of the items in Tables I and II. 


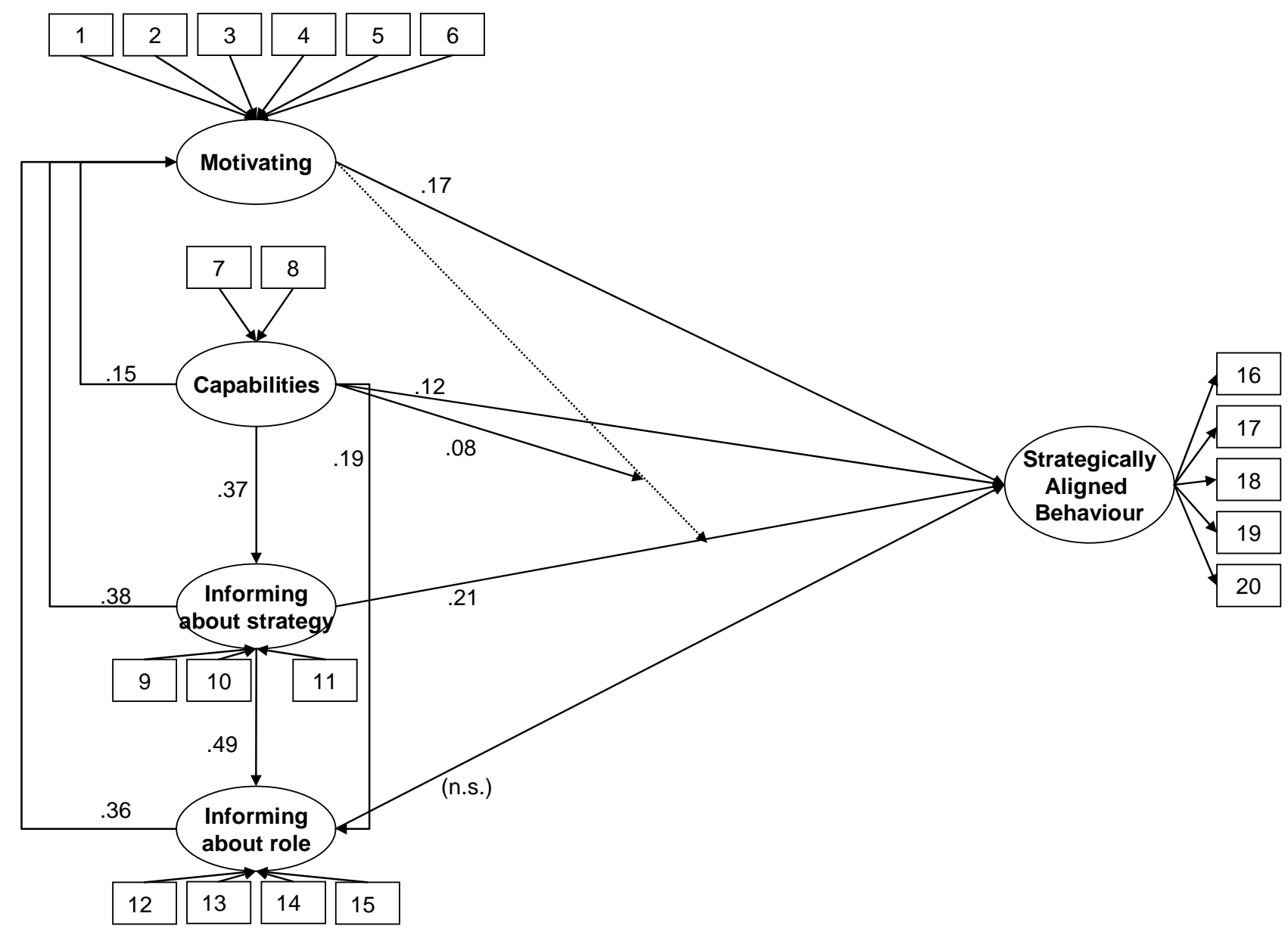

Figure 2. Results of the model for Organisation 1 
Strategically aligned behaviour

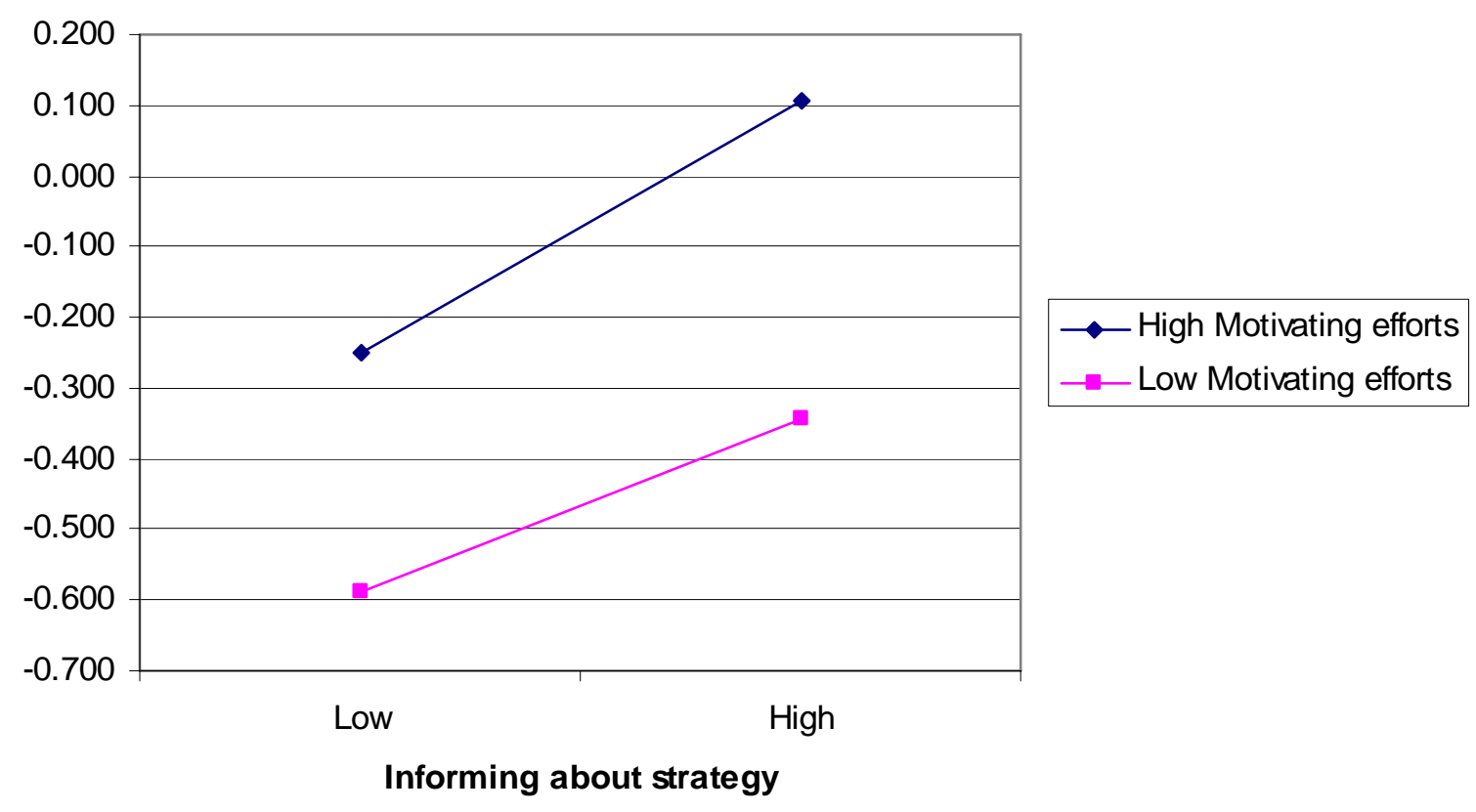

Figure 3. Interaction between Motivating efforts, Capability development, and Informing efforts (Organisation 1) 


\section{Strategically}

\section{Aligned Behaviour}

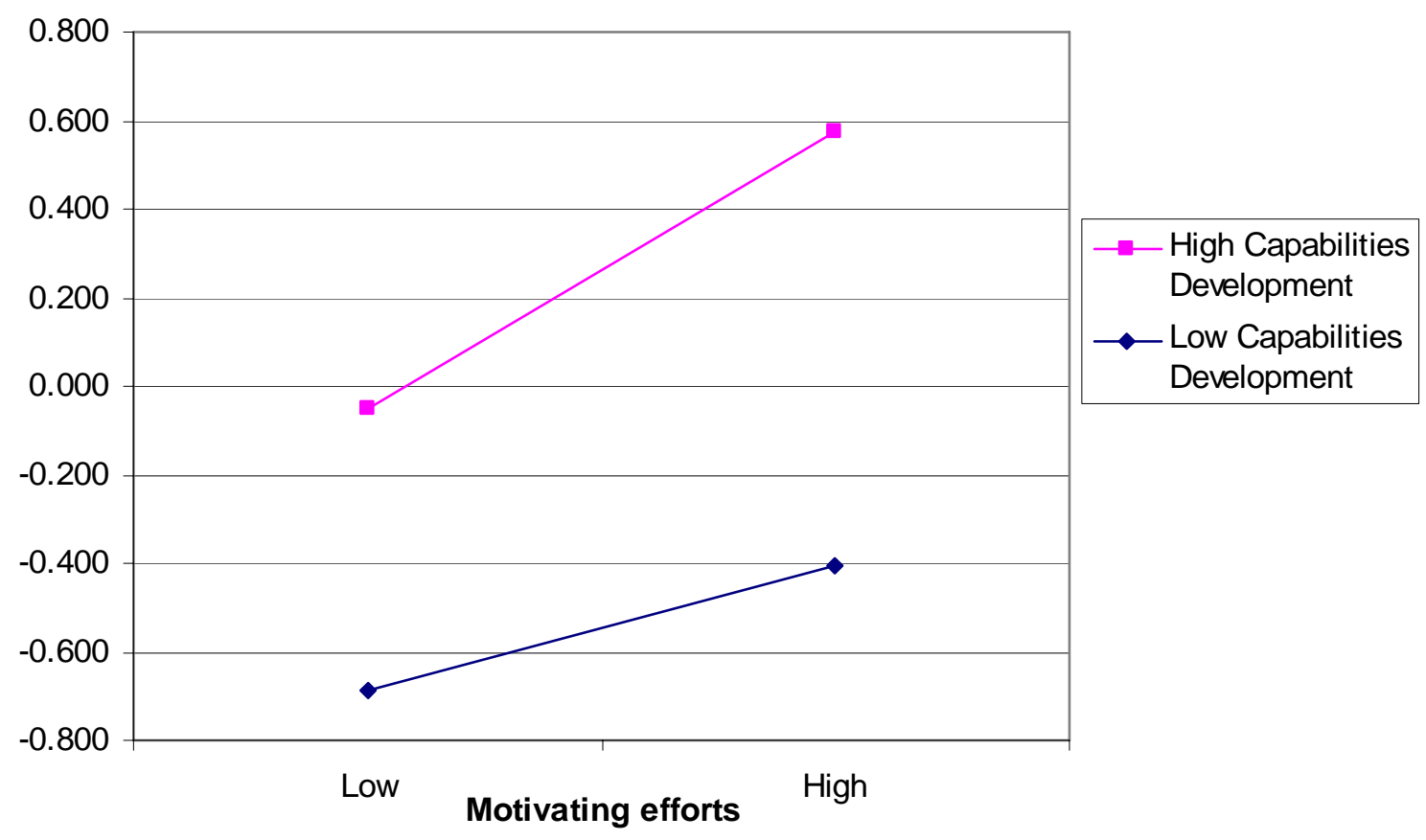

Figure 4. Interaction between Motivating efforts and Capability development (Organisation 2) 


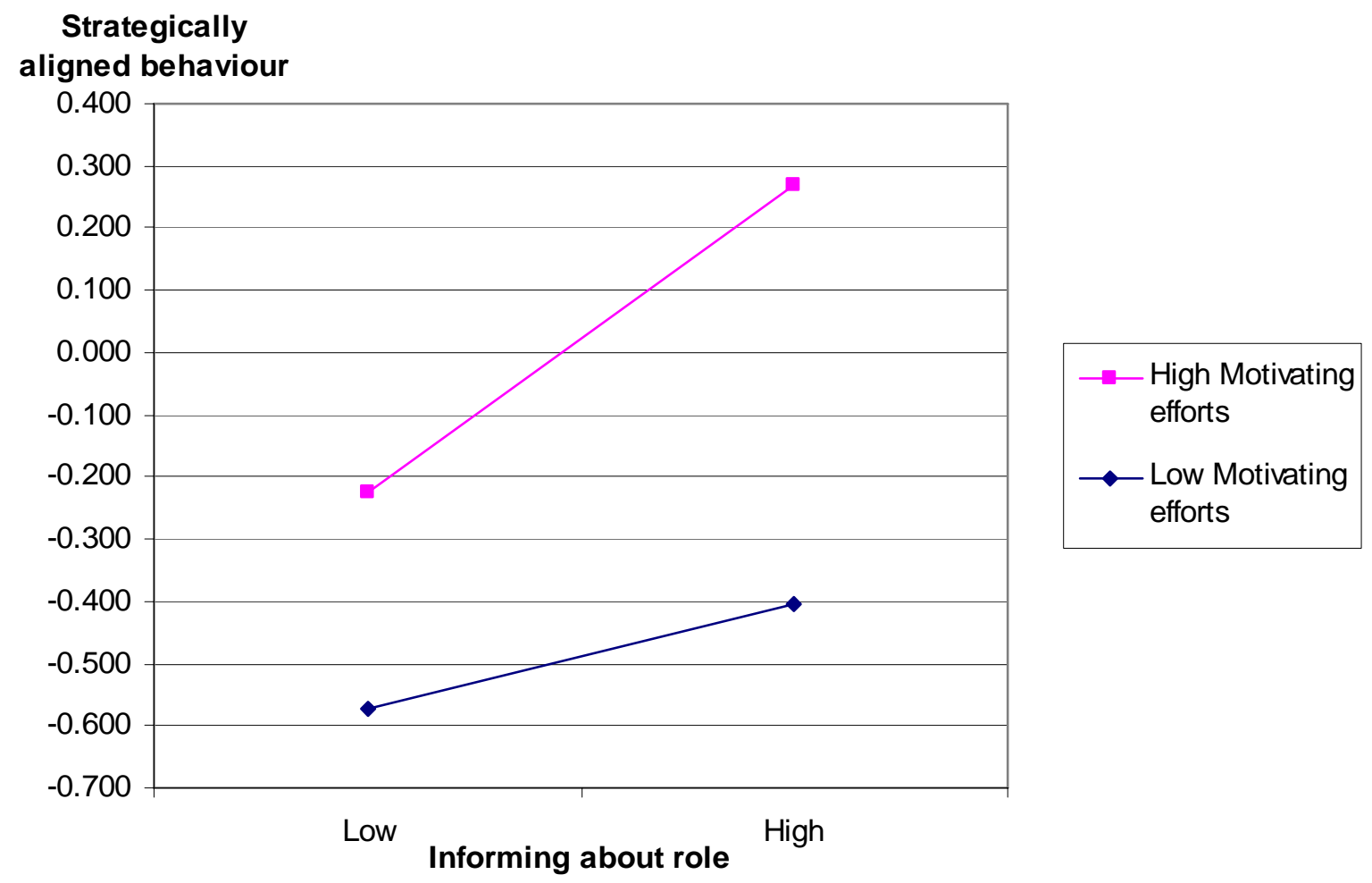

Figure 5. Interaction between Informing about role and Motivating efforts (Organisation 3) 
Table I. Means and standard deviations (Organisation 1)

\begin{tabular}{|rlrr|}
\hline & & Mean & S.D. \\
\hline 1 & Motivating efforts (1) & 3.36 & 0.91 \\
\hline 2 & Motivating efforts (2) & 3.58 & 1.02 \\
\hline 3 & Motivating efforts (3) & 3.41 & 1.00 \\
\hline 4 & Motivating efforts (4) & 3.32 & 0.86 \\
\hline 5 & Motivating efforts (5) & 3.47 & 0.86 \\
\hline 6 & Motivating efforts (6) & 3.57 & 0.78 \\
\hline 7 & Capability development (1) & 3.51 & 0.88 \\
\hline 8 & Capability development (2) & 3.36 & 0.92 \\
\hline 9 & Informing about strategy (1) & 3.54 & 0.95 \\
\hline 10 & Informing about strategy (2) & 3.51 & 0.82 \\
\hline 11 & Informing about strategy (3) & 3.42 & 0.88 \\
\hline 12 & Informing about role (1) & 3.34 & 0.82 \\
\hline 13 & Informing about role (2) & 3.35 & 0.96 \\
\hline 14 & Informing about role (3) & 3.13 & 0.96 \\
\hline 15 & Informing about role (4) & 3.33 & 0.91 \\
\hline 16 & SAB (1) & 3.49 & 0.84 \\
\hline 17 & SAB (2) & 3.40 & 0.82 \\
\hline 18 & SAB (3) & 3.50 & 0.82 \\
\hline 19 & SAB (4) & 3.39 & 0.81 \\
\hline 20 & SAB (5) & 0.81 \\
\hline & & \\
\hline
\end{tabular}


Table II. Correlations (Organisation 1).

\begin{tabular}{|c|c|c|c|c|c|c|c|c|c|c|c|c|c|c|c|c|c|c|c|c|}
\hline & & 1 & 2 & 3 & 4 & 5 & 6 & 7 & 8 & 9 & 10 & 11 & 12 & 13 & 14 & 15 & 16 & 17 & 18 & 19 \\
\hline 1 & Motivating efforts (1) & & & & & & & & & & & & & & & & & & & \\
\hline 2 & Motivating efforts (2) & 0.28 & & & & & & & & & & & & & & & & & & \\
\hline 3 & Motivating efforts (3) & 0.29 & 0.68 & & & & & & & & & & & & & & & & & \\
\hline 4 & Motivating efforts (4) & 0.31 & 0.26 & 0.30 & & & & & & & & & & & & & & & & \\
\hline 5 & Motivating efforts (5) & 0.39 & 0.31 & 0.32 & 0.50 & & & & & & & & & & & & & & & \\
\hline 6 & Motivating efforts (6) & 0.34 & 0.31 & 0.34 & 0.45 & 0.59 & & & & & & & & & & & & & & \\
\hline 7 & Capability development (1) & 0.17 & 0.17 & 0.16 & 0.21 & 0.26 & 0.26 & & & & & & & & & & & & & \\
\hline 8 & Capability development (2) & 0.23 & 0.28 & 0.24 & 0.24 & 0.34 & 0.27 & 0.36 & & & & & & & & & & & & \\
\hline 9 & Informing - strategy (1) & 0.56 & 0.30 & 0.22 & 0.28 & 0.42 & 0.30 & 0.14 & 0.25 & & & & & & & & & & & \\
\hline 10 & Informing - strategy (2) & 0.37 & 0.32 & 0.33 & 0.36 & 0.47 & 0.32 & 0.21 & 0.28 & 0.45 & & & & & & & & & & \\
\hline 11 & Informing - strategy (3) & 0.27 & 0.28 & 0.25 & 0.29 & 0.33 & 0.25 & 0.20 & 0.28 & 0.33 & 0.45 & & & & & & & & & \\
\hline 12 & Informing - role (1) & 0.30 & 0.18 & 0.19 & 0.25 & 0.25 & 0.19 & 0.15 & 0.20 & 0.24 & 0.26 & 0.21 & & & & & & & & \\
\hline 13 & Informing - role (2) & 0.34 & 0.42 & 0.42 & 0.38 & 0.41 & 0.43 & 0.21 & 0.29 & 0.35 & 0.45 & 0.37 & 0.29 & & & & & & & \\
\hline 14 & Informing - role (3) & 0.30 & 0.39 & 0.41 & 0.38 & 0.38 & 0.39 & 0.16 & 0.29 & 0.31 & 0.46 & 0.39 & 0.27 & 0.73 & & & & & & \\
\hline 15 & Informing - role (4) & 0.28 & 0.38 & 0.40 & 0.33 & 0.35 & 0.39 & 0.20 & 0.31 & 0.28 & 0.37 & 0.33 & 0.23 & 0.62 & 0.60 & & & & & \\
\hline 16 & SAB (1) & 0.20 & 0.26 & 0.24 & 0.23 & 0.26 & 0.24 & 0.15 & 0.26 & 0.29 & 0.26 & 0.33 & 0.11 & 0.26 & 0.25 & 0.24 & & & & \\
\hline & SAB (2) & 0.25 & 0.29 & 0.26 & 0.19 & 0.29 & 0.28 & 0.19 & 0.30 & 0.32 & 0.27 & 0.35 & 0.09 & 0.28 & 0.26 & 0.28 & 0.69 & & & \\
\hline & SAB (3) & 0.22 & 0.26 & 0.23 & 0.23 & 0.27 & 0.29 & 0.13 & 0.27 & 0.29 & 0.22 & 0.28 & 0.10 & 0.28 & 0.24 & 0.30 & 0.66 & 0.68 & & \\
\hline 19 & SAB (4) & 0.23 & 0.27 & 0.26 & 0.24 & 0.30 & 0.30 & 0.14 & 0.25 & 0.30 & 0.25 & 0.31 & 0.14 & 0.32 & 0.28 & 0.31 & 0.62 & 0.68 & 0.78 & \\
\hline & SAB(5) & 0.23 & 0.30 & 0.26 & 0.24 & 0.30 & 0.31 & 0.16 & 0.27 & 0.31 & 0.25 & 0.29 & 0.12 & 0.34 & 0.30 & 0.32 & 0.62 & 0.70 & 0.80 & 0.85 \\
\hline
\end{tabular}


Table III. Model comparison among the three organisations

\begin{tabular}{|c|c|c|c|c|c|c|c|c|}
\hline & & & \multicolumn{2}{|c|}{ Organisation 1} & \multicolumn{2}{|c|}{ Organisation 2} & \multicolumn{2}{|c|}{ Organisation 3} \\
\hline & Independent variable & Dependent variable & Path & ES & Path & ES & Path & ES \\
\hline \multirow{10}{*}{$\begin{array}{l}\text { Main } \\
\text { effects }\end{array}$} & Motivating efforts & SAB & $.17^{\star \star}$ & .01 & $.22^{\star \star}$ & .04 & $.26^{\star \star}$ & .04 \\
\hline & \multirow[t]{4}{*}{ Capability development } & SAB & $.12^{\star \star}$ & .02 & $.40^{\star \star}$ & .16 & $.29 * *$ & .10 \\
\hline & & Motivating efforts & $.16^{\star \star}$ & .05 & $.11^{\star \star}$ & .02 & $.12^{\star \star}$ & .03 \\
\hline & & Informing about strategy & $.34^{\star \star}$ & .12 & $.31^{\star \star}$ & .09 & $.33^{\star \star}$ & .11 \\
\hline & & Informing about role & $.17^{\star \star}$ & .03 & $.16^{\star \star}$ & .03 & $.21^{\star \star}$ & .05 \\
\hline & \multirow[t]{3}{*}{ Informing about strategy } & SAB & $.21^{\star \star}$ & .03 & .05 & (n.s.) & .07 & (n.s.) \\
\hline & & Motivating efforts & $.37^{\star \star}$ & .16 & $.44^{\star \star}$ & .22 & $.56^{\star \star}$ & .35 \\
\hline & & Informing about role & $.46^{\star \star}$ & .20 & $.29 * *$ & .08 & $.33^{\star \star}$ & .11 \\
\hline & \multirow[t]{2}{*}{ Informing about role } & SAB & .08 & (n.s.) & .07 & (n.s.) & $.15^{\star \star}$ & .02 \\
\hline & & Motivating efforts & $.36^{\star \star}$ & .16 & $.30^{\star \star}$ & .12 & $.22^{\star \star}$ & .07 \\
\hline \multirow{5}{*}{$\begin{array}{l}\text { 2-way } \\
\text { interactions }\end{array}$} & Motivating x Capability development & SAB & -.08 & (ns) & $.09^{*}$ & .01 & -.08 & (n.s.) \\
\hline & Motivating $x$ Informing about strategy & SAB & .06 & (ns) & -.05 & (ns) & -.03 & (n.s.) \\
\hline & Motivating $\mathrm{x}$ Informing about role & SAB & -.00 & (ns) & .02 & (ns) & $.08^{\star}$ & .01 \\
\hline & $\begin{array}{l}\text { Capability development } x \text { Informing about } \\
\text { strategy }\end{array}$ & SAB & -.03 & (ns) & -.03 & (ns) & .02 & (n.s.) \\
\hline & $\begin{array}{l}\text { Capability development } x \text { Informing about } \\
\text { role }\end{array}$ & SAB & .02 & (ns) & .01 & (ns) & -.01 & (n.s.) \\
\hline \multirow[t]{2}{*}{$\begin{array}{l}\text { 3-way } \\
\text { interactions }\end{array}$} & $\begin{array}{l}\text { Motivating } x \text { Capability development } x \\
\text { Informing about strategy }\end{array}$ & SAB & $.08^{*}$ & .01 & .05 & (ns) & .00 & (n.s.) \\
\hline & $\begin{array}{l}\text { Motivating } x \text { Capability development } x \\
\text { Informing about role }\end{array}$ & SAB & -.05 & (ns) & -.03 & (ns) & .00 & (n.s.) \\
\hline \multirow{4}{*}{$\begin{array}{l}\text { Overall } \\
\text { model fit }\end{array}$} & \multicolumn{2}{|c|}{$\mathrm{R}^{2}$ for $\mathrm{SAB}$ (including interactions) } & \multicolumn{2}{|c|}{.27} & \multicolumn{2}{|c|}{.34} & \multicolumn{2}{|c|}{.36} \\
\hline & \multicolumn{2}{|c|}{$\mathrm{R}^{2}$ for Motivating efforts } & \multicolumn{2}{|c|}{.53} & \multicolumn{2}{|c|}{.46} & \multicolumn{2}{|c|}{.56} \\
\hline & \multirow{2}{*}{\multicolumn{2}{|c|}{$\frac{\mathrm{R}^{2} \text { for Informing about strategy }}{\mathrm{R}^{2} \text { for Informing about role }}$}} & \multirow{2}{*}{\multicolumn{2}{|c|}{.20}} & \multirow{2}{*}{\multicolumn{2}{|c|}{$\begin{array}{l}.13 \\
.17\end{array}$}} & \multicolumn{2}{|c|}{.12} \\
\hline & & & & & & & & \\
\hline
\end{tabular}

$* *: \mathrm{p}<.01 ; *: \mathrm{p}<.05$.

Because statistical power is generally lower for interactions than for main effects (Cohen, 1988), we used an alpha of 0.05 for the interaction effects and an alpha of 0.01 for the main effects. In addition, the main effects reported are those obtained in the model without interaction effects, as main effects cannot be interpreted as such in a model in which significant interaction effects are present (Jaccard et al., 1990). Similarly, the two-way interactions reported are those obtained in the model without three-way interactions. 


\section{References}

Argyris, C. (1957). Personality and Organization: the Conflict between System and the Individual. New York: Harper \& Brothers.

Bandura, A. (1997). Self-efficacy: the Exercise of Control. New York: W. H. Freeman.

Besser, T. L. (1995). 'Rewards and organizational goal achievement: a case study of Toyota Motor Manufacturing in Kentucky'. Journal of Management Studies, 32, 383-399.

Bloodgood, J. M. and Morrow, J. L. (2003). 'Strategic organizational change: exploring the roles of environmental structure, internal conscious awareness and knowledge'. Journal of Management Studies, 40, 1761-1782.

Blumberg, M. and Pringle, C. D. (1982). 'The missing opportunity in organizational research: some implications for a theory of work performance'. Academy of Management Review, 7, 560-569.

Bordia, P., Hobman, E., Jones, E., Gallois, C. and Callan, V. (2004). 'Uncertainty during organizational change: types, consequences, and management strategies'. Journal of Business and Psychology, 18, 507-532.

Boswell, W. R. (2006). 'Aligning employees with the organization's strategic objectives: out of 'line of sight', out of mind'. International Journal of Human Resource Management, 17, 1489-1511.

Bowen, F. and Blackmon, K. (2003). 'Spirals of silence: the dynamic effects of diversity on organizational voice'. Journal of Management Studies, 40, 1393-1417.

Bowman, C. and Ambrosini, V. (1997). 'Perceptions of strategic priorities, consensus and firm performance'. Journal of Management Studies, 34, 241-258.

Caldwell, S. D., Herold, D. M. and Fedor, D. B. (2004). 'Toward an understanding of the relationships among organizational change, individual differences, and changes in person-environment fit: a cross-level study'. Journal of Applied Psychology, 89, 868-882.

Carter, C. R., Auskalnis, R. J. and Ketchum, C. L. (1999). 'Purchasing from minority business enterprises: key success factors'. Journal of Supply Chain Management, 35, 28-32. 
Chatman, J. A. (1989). 'Matching people and organizations: selection and socialization in public accounting firms'. Administrative Science Quarterly, 36, 459-484.

Chin, W. W., Marcolin, B. L. and Newsted, P. R. (2003). 'A partial least squares latent variable modeling approach for measuring interaction effects: results from a Monte Carlo simulation study and an electronic-mail emotion/adoption study'. Information Systems Research, 14, 189-217.

Cohen, J. (1988). Statistical Power Analysis for the Behavioral Sciences. Hillsdale, NJ: Lawrence Erlbaum.

Cornelissen, J., Van Bekkum, T. and Van Ruler, B. (2006). 'Corporate communications: a practice-based theoretical conceptualization'. Corporate Reputation Review, 9, 114-133.

Diamantopoulos, A. and Winklhofer, H. M. (2001). 'Index construction with formative indicators: An alternative to scale development'. Journal of Marketing Research, 38, 269277.

Evans, M. G. (1985). 'A Monte Carlo study of the effects of correlated method variance in moderated multiple regression analysis'. Organizational behavior and human decision processes, 36, 305-323.

Fazio, R. H. and Zanna, M. P. (1981). 'Direct experience and attitude-behavior consistency'. Advances in Experimental Social Psychology, 14, 161-202.

Fisher, R. J. (1993). 'Social desirability bias and the validity of indirect questioning'. Journal of Consumer Research, 20, 303-315.

Gagné, M., Koestner, R. and Zuckerman, M. (2000). 'Facilitating acceptance of organizational change: the importance of self-determination'. Journal of Applied Social Psychology, 30, 1843-1852.

Gagnon, M. A. and Michael, J. H. (2003). 'Employee strategic alignment at a wood manufacturer: An exploratory analysis using lean manufacturing'. Forest Products Journal, 53, 24-29.

Grewal, R., Cote, J. A. and Baumgartner, H. (2004). 'Multicollinearity and measurement error in structural equation models: implications for theory testing'. Marketing Science, 23, 519529.

Gupta, A. K. (1987). 'SBU strategies, corporate-SBU relations, and SBU effectiveness in strategy implementation'. Academy of Management Journal, 30, 477-500. 
Hambrick, D. C. and Cannnella, A. A. (1989). 'Strategy implementation as substance and selling'. Academy of Management Executive, 3, 278-285.

Hui, C. and Lee, C. (2000). 'Moderating effects of organization-based self-esteem on organizational uncertainty: employee response relationships'. Journal of Management, 26, 215-232.

Ichniowksi, C., Kochan, T. A., Levine, D., Olson, C. and Strauss, G. (1996). 'What works at work: overview and assessment'. Industrial Relations, 35, 299-333.

Jaccard, J., Turrisi, R. and Wan, C. K. (1990). Interaction Effects in Multiple Regression (Vol. 07-072). Newbury Park, CA: Sage.

Jarvis, C. B., MacKenzie, S. B. and Podsakoff, P. M. (2003). 'A critical review of construct indicators and measurement model misspecification in marketing and consumer research'. Journal of Consumer Research, 30, 199-218.

Johnson, G., Melin, L. and Whittington, R. (2003). 'Micro strategy and strategizing: towards an activity-based view'. Journal of Management Studies, 40, 3-22.

Judge, T. A., Shaw, J. C., Jackson, C. L., Scott, B. A. and Rich, B. L. (2007). 'Self-efficacy and work-related performance: the integral role of individual differences'. Journal of Applied Psychology, 92, 107-127.

Kane, J. S. (1997). 'Assessment of the situational and individual components of job performance'. Human Performance, 10, 193-226.

Kellermanns, F. W., Walter, J., Lechner, C. and Floyd, S. W. (2005). 'The lack of consensus about strategic consensus: advancing theory and research'. Journal of Management, 31, 719-737.

Kreiner, G. E. and Ashforth, B. E. (2004). 'Evidence toward an expanded model of organizational identification'. Journal of Organizational Behavior, 25, 1-27.

Latham, G. P., Erez, M. and Locke, E. A. (1988). 'Resolving scientific disputes by the joint design of crucial experiments by the antagonists: application to the Erez-Latham dispute regarding participation in goal setting'. Journal of Applied Psychology, 73, 753-772.

Lee, J. and Miller, D. (1999). 'People matter: commitment to employees, strategy and performance in Korean firms'. Strategic Management Journal, 20, 579-593. 
LePine, J. A., Erez, A. and Johnson, D. E. (2002). 'The nature and dimensionality of organizational citizenship behavior: a critical review and meta-analysis'. Journal of Applied Psychology, 87, 52-65.

Li, Y. (2005). PLS-GUI: a graphic user interface for Lvpls (PLS 1.8 PC) (Version 2.0.1). Columbia, SC: University of South Carolina.

Louis, M. R., Posner, B. Z. and Powell, G. N. (1983). 'The availability and helpfulness of socialization practices'. Personnel Psychology, 36, 857-866.

Mathieu, J. E. and Zajac, D. M. (1990). 'A review and meta-analysis of the antecedents, correlates, and consequences of organizational commitment'. Psychological Bulletin, 108, 171-194.

McMullen, J. S. and Shepherd, D. A. (2006). 'Encouraging consensus-challenging research in universities'. Journal of Management Studies, 43, 1643-1669.

Mitchell, T. R. and Larson, J. R. (1987). People in Organizations: an Introduction to Organizational Behavior. New York: McGraw-Hill.

Moorman, R. H. and Blakely, G. L. (1995). 'Individualism-collectivism as an individual difference predictor of organizational citizenship behavior'. Journal of Organizational Behavior, 16, 127-142.

Morrison, E. W. and Milliken, F. J. (2000). 'Organizational silence: a barrier to change and development in a pluralistic world'. Academy of Management Review, 25, 706-725.

Noble, C. H. (1999). 'The eclectic roots of strategy implementation research'. Journal of Business Research, 45, 119-134.

Noble, C. H. and Mokwa, M. P. (1999). 'Implementing marketing strategies: developing and testing a managerial theory'. Journal of Marketing, 63, 57-73.

Peters, L. H., Fisher, C. D. and O'Connor, E. J. (1982). 'The moderating effect of situational control of performance variance on the relationship between individual differences and performance'. Personnel Psychology, 35, 609-621.

Peters, L. H. and O'Connor, E. J. (1980). 'Situational constraints and work outcomes: the influences of a frequently overlooked construct'. Academy of Management Review, 5, 391-397.

Piercy, N. F., Cravens, D. W., Lane, N. and Vorhies, D. W. (2006). 'Driving organizational citizenship behaviors and salesperson in-role behavior performance: the role of 
management control and perceived organizational support'. Journal of the Academy of Marketing Science, 34, 244-262.

Podsakoff, P. M., MacKenzie, S. B., Lee, J.-Y. and Podsakoff, N. P. (2003). 'Common method biases in behavioral research: a critical review of the literature and recommended remedies'. Journal of Applied Psychology, 88, 879-903.

Pringle, C. D. (1994). 'An initial test of a theory of individual performance'. Psychological Reports, 74, 963-973.

Rapert, M. I., Velliquette, A. and Garretson, J. A. (2002). 'The strategic implementation process: evoking consensus through communication'. Journal of Business Research, 55, 301-310.

Sagie, A. and Koslowsky, M. (1994). 'Organizational attitudes and behaviors as a function of participation in strategic and tactical change decisions: an application of path-goal theory'. Journal of Organizational Behavior, 15, 37-47.

Schmidt, F. L., Hunter, J. E. and Outerbridge, A. N. (1986). 'Impact of job experience and ability on job knowledge, work sample performance, and supervisory ratings of job performance'. Journal of Applied Psychology, 71, 432-439.

Schneider, B., Hayes, S. C., Lim, B.-C., Raver, J. L., Godfrey, E. G., Huang, M., et al. (2003). 'The human side of strategy: employee experiences of strategic alignment in a service organization'. Organizational Dynamics, 32, 122-141.

Schweiger, D. M. and Denisi, A. S. (1991). 'Communication with employees following a merger: a longitudinal field experiment'. Academy of Management Journal, 34, 110-135.

Skivington, J. E. and Daft, R. L. (1991). 'A study of organizational 'framework' and 'process' modalities for the implementation of business-level strategic decisions'. Journal of Management Studies, 28, 45-68.

Smidts, A., Pruyn, A. T. H. and Van Riel, C. B. M. (2001). 'The impact of employee communication and perceived external prestige on organizational identification'. Academy of Management Journal, 49, 1051-1062.

Stewart, G. L. and Nandkeolyar, A. K. (2006). 'Adaptation and intraindividual variation in sales outcomes: exploring the interactive effects of personality and environmental opportunity'. Personnel Psychology, 59, 307-332. 
Strahle, W. M., Spiro, R. L. and Acito, F. (1996). 'Marketing and sales: Strategic alignment and functional implementation'. The Journal of Personal Selling \& Sales Management, 16, 120.

Tenenhaus, M., Vinzi, V. E., Chatelin, Y.-M. and Lauro, C. (2005). 'PLS path modeling'. Computational Statistics and Data Analysis, 48, 159-205.

Vroom, V. H. (1960). Some Personality Determinants of the Effects of Participation. Englewood Cliffs, NJ: Prentice Hall.

Vroom, V. H. (1964). Work and Motivation. New York: John Wiley.

Wooldridge, B. and Floyd, S. W. (1989). 'Strategic process effects on consensus'. Strategic Management Journal, 10, 295-302.

\footnotetext{
${ }^{\mathrm{i}}$ In PLS the weights of the indicators are determined as a function of the relationships among the constructs; therefore, they are an indication of external (predictive) as well as internal validity (Tenenhaus et al., 2005).

ii We derived a measure of understanding by coding respondents' answers to the questions about the meaning of the strategy as either "right" or "wrong”. We used a coding scheme based on information about the strategy provided by the organisations. We also verified this scheme by asking managers from the organisations to review it.
} 


\section{Publications in the ERIM Report Series Research* in Management}

\section{ERIM Research Program: "Organizing for Performance"}

2007

Leadership Behaviour and Upward Feedback: Findings From a Longitudinal Intervention

Dirk van Dierendonck, Clare Haynes, Carol Borrill and Chris Stride

ERS-2007-003-ORG

http://hdl.handle.net/1765/8579

The Clean Development Mechanism: Institutionalizing New Power Relations

Bettina B.F. Wittneben

ERS-2007-004-ORG

http://hdl.handle.net/1765/8582

How Today's Consumers Perceive Tomorrow's Smart Products

Serge A. Rijsdijk and Erik Jan Hultink

ERS-2007-005-ORG

http://hdl.handle.net/1765/8984

Product Intelligence: Its Conceptualization, Measurement and Impact on Consumer Satisfaction

Serge A. Rijsdijk, Erik Jan Hultink and Adamantios Diamantopoulos

ERS-2007-006-ORG

http://hdl.handle.net/1765/8580

Testing the Strength of the Iron Cage: A Meta-Analysis of Neo-Institutional Theory

Pursey P.M.A.R. Heugens and Michel Lander

ERS-2007-007-ORG

http://hdl.handle.net/1765/8581

Export Orientation among New Ventures and Economic Growth

S. Jolanda A. Hessels and André van Stel

ERS-2007-008-ORG

http://hdl.handle.net/1765/8583

Allocation and Productivity of Time in New Ventures of Female and Male Entrepreneurs

Ingrid Verheul, Martin Carree and Roy Thurik

ERS-2007-009-ORG

http://hdl.handle.net/1765/8989

Cooperating if one's Goals are Collective-Based: Social Identification Effects in Social Dilemmas as a Function of Goal-Transformation David De Cremer, Daan van Knippenberg, Eric van Dijk and Esther van Leeuwen

ERS-2007-010-ORG

http://hdl.handle.net/1765/9041

Unfit to Learn? How Long View Organizations Adapt to Environmental Jolts

Pursey P. M. A. R. Heugens and Stelios C. Zyglidopoulos

ERS-2007-014-ORG

http://hdl.handle.net/1765/9404

Going, Going, Gone. Innovation and Exit in Manufacturing Firms

Elena Cefis and Orietta Marsili

ERS-2007-015-ORG

http://hdl.handle.net/1765/9732 
High in the Hierarchy: How Vertical Location and Judgments of Leaders' Power are Interrelated Steffen R. Giessner and Thomas W. Schubert

ERS-2007-021-ORG

http://hdl.handle.net/1765/9727

Contracts to Communities: a Processual Model of Organizational Virtue

Pursey P.M.A.R. Heugens, Muel Kaptein and J. van Oosterhout

ERS-2007-023-ORG

http://hdl.handle.net/1765/9728

Why Are Some Entrepreneurs More Innovative Than Others?

Philipp Koellinger

ERS-2007-024-ORG

http://hdl.handle.net/1765/9730

Stimulating Strategically Aligned Behaviour Among Employees

Cees B. M. van Riel, Guido Berens and Majorie Dijkstra

ERS-2007-029-ORG

The Effectiveness of Business Codes: A Critical Examination of Existing Studies and the Development of an Integrated Research Model

Muel Kaptein and Mark Schwartz

ERS-2007-030-ORG

* A complete overview of the ERIM Report Series Research in Management https://ep.eur.nl/handle/1765/1

ERIM Research Programs:

LIS Business Processes, Logistics and Information Systems

ORG Organizing for Performance

MKT Marketing

F\&A Finance and Accounting

STR Strategy and Entrepreneurship 